\title{
Obstructive renal injury: from fluid mechanics to molecular cell biology
}

This article was published in the following Dove Press journal:

Open Access Journal of Urology

21 April 2010

Number of times this article has been viewed

\author{
Alvaro C Ucerol,* \\ Sara Gonçalves ${ }^{2, *}$ \\ Alberto Benito-Martin' \\ Beatriz Santamaría' \\ Adrian M Ramos' \\ Sergio Berzal' \\ Marta Ruiz-Ortega' \\ Jesus Egido' \\ Alberto Ortiz' \\ 'Fundación Jiménez Díaz, Universidad \\ Autónoma de Madrid, Fundación \\ Renal Iñigo Alvarez de Toledo, Madrid, \\ Spain; ${ }^{2}$ Nefrologia e Transplantação \\ Renal, Hospital de Santa Maria EPE, \\ Lisbon, Portugal \\ *Both authors contributed equally to \\ the manuscript
}

Correspondence: Alberto Ortiz

Unidad de Diálisis, Fundación Jiménez

Díaz, Av Reyes Católicos 2,

28040 Madrid, Spain

Tel +34 9l 5504940

Fax +34915494764

Email aortiz@fjd.es
Abstract: Urinary tract obstruction is a frequent cause of renal impairment. The physiopathology of obstructive nephropathy has long been viewed as a mere mechanical problem. However, recent advances in cell and systems biology have disclosed a complex physiopathology involving a high number of molecular mediators of injury that lead to cellular processes of apoptotic cell death, cell injury leading to inflammation and resultant fibrosis. Functional studies in animal models of ureteral obstruction using a variety of techniques that include genetically modified animals have disclosed an important role for the renin-angiotensin system, transforming growth factor- $\beta 1$ (TGF- $\beta 1$ ) and other mediators of inflammation in this process. In addition, high throughput techniques such as proteomics and transcriptomics have identified potential biomarkers that may guide clinical decision-making.

Keywords: urinary tract obstruction, renal injury, fluid mechanics, molecular cell biology

\section{The scope of the problem}

Urinary tract obstruction (UTO) is a common clinical problem and a frequent cause of renal impairment. It is defined as a physical blockage to urine flow, which may result in hydronephrosis and ultimately renal parenchymal damage. UTO has a bimodal distribution in incidence, occurring in the very young and in the elderly. The incidence of antenatal hydronephrosis, including transient and physiological hydronephrosis, is 1:100 to $1: 500 .{ }^{1}$ In children, UTO is a frequent cause of end-stage renal disease (ESRD), accounting for $21 \%$ of chronic kidney disease (CKD) and for $16 \%$ of children listed for transplantation. ${ }^{2}$ In the UK, obstructive kidney disease is the third most common etiology for CKD in children, accounting for $15 \%$ of the cases. ${ }^{3}$

In adults, UTO is a frequent cause of acute kidney injury (AKI). Up to $17 \%$ of AKI are secondary to UTO, most commonly due to prostatic disease. ${ }^{4}$ It also accounts for $3 \%-5 \%$ of ESRD in patients older than 65 years. ${ }^{5}$ In the United States, renal replacement therapy as a result of acquired obstruction accounts for $1.4 \%$ of prevalent patients. ${ }^{6}$

The major etiologies of UTO vary with patient age. Anatomic abnormalities are commonly seen in children while acquired causes are more frequent in adults. Ureteropelvic junction (UPJ) obstruction is the most common anatomic cause of hydronephrosis detected in utero with an incidence of 1:2000. ${ }^{7,8}$ Other causes of obstruction in children include ureterovesical junction obstruction, posterior urethral valves, urethral atresia or stricture and neuropathic bladder. Prostatic obstruction, tumors, nephrolithiasis, ureteral strictures and retroperitoneal fibrosis are the primary causes of UTO in adults. ${ }^{9,10}$ 
Untreated urinary obstruction can lead to tubular atrophy, interstitial fibrosis and inflammation, loss of nephrons and ultimately irreversible renal injury. ${ }^{5,11}$ If both kidneys are affected or if there is only one kidney, ESRD will result. The renal prognosis after relief of UTO is dependent upon the severity and the duration of the obstruction. In fact, there is complete recovery of glomerular filtration rate (GFR) following relief of a one-week total ureteral obstruction, whereas almost no recovery occurs after 12 weeks. ${ }^{11}$ Fetal or neonatal UTO is further complicated by the deleterious effects of obstruction on a maturing kidney, which may lead to renal dysplasia and delayed nephron maturation, besides nephron loss. ${ }^{12}$ Moreover, intrauterine severe bilateral UTO can lead to oligohydramnios with subsequent pulmonary hypoplasia and respiratory failure at birth and limb deformations or even early neonatal death. ${ }^{13,14}$ Other important clinical sequelae of UTO are tubular disorders such as sodium wasting, type IV renal tubular acidosis and impaired water excretion. ${ }^{8}$

Treatment of UTO is dictated by the underlying cause, the location of the obstruction, and the degree of renal impairment. For example, complete bilateral ureteral obstruction presenting as AKI is a medical emergency and requires prompt relief of the obstruction to decompress the kidneys and salvage renal function. In adults, most causes of UTO are amenable to therapy and the prognosis is generally good, depending on the underlying disease. However, in children, especially when regarding UPJ obstruction, the indications for surgical intervention are not so clear-cut and the evaluation and management of obstructive nephropathy remains challenging. ${ }^{15}$ Repeated diagnostic tests and prolonged periods of follow-up are common, potentially resulting in irreversible kidney injury.

\section{Classical pathophysiology of obstructive nephropathy}

UTO is classified according to the degree, duration, and site of the obstruction. ${ }^{16}$ The degree of obstruction is said to be high grade when it is complete and low grade when partial or incomplete. UTO can be further classified as acute or chronic, and depending on the site of the obstruction it can affect one or both kidneys.

UTO was for many years considered a mere physics problem. The onset of UTO leads to an initial increase in pressure proximal to the obstruction due to continued glomerular filtration. This rise in pressure dilates the collecting systems and is transmitted back to the distal and proximal tubules. Increased pressure on the proximal tubule leads to a decrease of the net hydraulic pressure gradient, thereby lowering the GFR. ${ }^{17}$ In addition, the rise in intratubular pressure induces secondary renal vasoconstriction, through humoral, neuronal and reflex phenomena, and thereby reduces the glomerular blood flow. ${ }^{18,19}$ This results in a blood shunt away from the nonfunctioning nephrons of the obstructed kidney and can thus be viewed as an appropriate physiologic response. ${ }^{20}$ The decrease in renal perfusion further reduces the GFR and thereby decreases intratubular pressures towards normal, starting 5 to 6 hours after urinary obstruction. ${ }^{21}$ However, the renal vascular resistance remains increased and may cause ischemia. ${ }^{19,22,23}$

\section{Cellular processes in obstructive renal injury}

In addition to the classical mechanical view of UTO, there is evidence that the pathophysiological process of nephron destruction, although initiated by an increased intratubular hydrostatic pressure and secondary ischemia, is later magnified by cellular processes that can be classified into three broad categories: tubulointerstitial inflammation, tubular cell death and fibrosis. ${ }^{18,24,25}$ Both the renin-angiotensinaldosterone system (RAS) and endothelin-1 (ET-1) contribute to renal vasoconstriction and also have a role in the interstitial inflammatory response, renal tubular cell loss, and, ultimately, fibrosis. ${ }^{26-31}$ Moreover, in the obstructed kidney, changes in intrarenal pressure cause mechanical stretch of tubular cells that are activated to release inflammatory, lethal and profibrotic mediators, such as transforming growth factor-beta (TGF- $\beta 1$ ) and others. ${ }^{32,33}$ By contrast, endogenous nitric oxide (NO) is increased in a compensatory fashion and partially counteracts the action of other vasoconstrictive systems. ${ }^{34}$ Most of the information on pathophysiological events has been generated in recent years using models of unilateral ureteral obstruction (UUO) in rats and mice. These models are of interest to both urologists and nephrologists, since they reproduce the cardinal features of progressive CKD in an accelerated fashion, thus facilitating their study.

\section{Interstitial inflammation}

Inflammation is a complex process that reflects the local and/or systemic responses to different stressors, and usually enables resistance to disease, repair of tissue damage and restoration of normal function with the least possible tissue damage. Local expression of cytokines, chemokines and membrane expression of adhesion molecules by injured parenchymal and endothelial cells recruits leukocytes to the site of injury and these cells in turn, amplify inflammation. While inflammation is usually an adaptive response to some 
aggression, if persistent or dysregulated, as in the case of UTO, it may contribute to tissue injury. Acute bacterial infection, such as acute pyelonephritis, will lead to a dramatic and obvious infiltration by neutrophils, however, in most kidney diseases inflammation is more subtle and macrophages and lymphocytes ("mononuclear cells") predominate. ${ }^{35,36}$

In the UUO model, interstitial infiltration by macrophages progressively increases from 12 hours after obstruction to up to 14 days. ${ }^{37,38}$ UTO shares mediators of inflammation with other forms of renal injury and with tissue injury in general. Key molecules in UTO renal inflammation include Angiotensin II (AngII) and the nuclear transcription factorkappaB (NF-кB).

AngII has a central role in initiation and progression of obstructive nephropathy, both directly and indirectly, by stimulating production of molecules that contribute to renal injury. ${ }^{39}$ AngII and tumor necrosis factor-alpha (TNF $\alpha$ ) are clearly upregulated in this model and together with other mediators activate NF- $\kappa \mathrm{B}$ and the transcription of NF-кB-dependent genes encoding chemokines, cytokines and growth factors, ${ }^{40-43}$ that include, in a positive feed-back loop, angiotensinogen and TNFo.$^{44-46}$ After a few hours of ureteral obstruction, a dramatic upregulation of adhesion molecules (ICAM-1 and VCAM-1), monocyte chemoattractive protein (MCP-1) and the glycoprotein osteopontin (OPN) is observed. ${ }^{37,47,48} \mathrm{MCP}-1$ attracts macrophages expressing its receptor CCR2 to the tubulointerstitium, ${ }^{49}$ whereas OPN, ICAM-1 and VCAM-1 mediate macrophage adhesion. The upregulated expression of these molecules persists up to 7-10 days from the obstruction. ICAM-1 and OPN seem to play its role within 5 days after obstruction, but MCP-1 and VCAM-1 gene induction continue increasing at those times. ${ }^{48-50}$ In later stages macrophage colony-stimulating factor-1 (MCSF-1) mRNA increased in association with local macrophage proliferation. ${ }^{51} \mathrm{NO}$ has different roles in inflammation that depend on the amount produced and this, in turn, the enzyme synthesizing NO. Thus constitutive expression of endothelial NO synthase (eNOS) yields low level NO, that inhibits leukocyte adhesion. ${ }^{52}$ Other mediators, such as TGF- $\beta 1$, contribute to NO degradation. ${ }^{53}$ Macrophages releases cytokines and growth factors and may contribute to apoptosis and tubulointerstitial fibrosis. ${ }^{54}$ One line of intense research is the different phenotypes of macrophages and their contribution to tissue repair.

\section{Tubular apoptosis}

Apoptosis is an energy-dependent cell death (cell suicide) which is triggered by injurious stimuli or the lack of survival factors. ${ }^{55,56}$ The balance between apoptosis and cell proliferation maintains cell number homeostasis in healthy organs. In UTO, tubular atrophy is the result of an increased rate of tubular cell apoptosis, with the contribution of other processes such as epithelial-mesenchymal transition (EMT) ${ }^{57}$ Most apoptosis in UUO takes place in tubular cells, but also interstitial cells undergo apoptosis. The latter may contribute to resolution of inflammation and repair of fibrosis. However, there is an incomplete understanding of the differential regulation of apoptosis in different cell types. One day after UUO tubular apoptosis is observed, whereas interstitial cells undergo apoptosis from 3 days after obstruction. Both augment in a time-dependent manner. ${ }^{58}$ After 12 days of UUO, tubular dilation and apoptosis peak in both the distal tubules and collecting duct throughout the cortex and medulla. Tubular apoptosis of the obstructed kidney showed strong correlation with the segment's degree of dilation. ${ }^{59}$

Among the most relevant players in apoptosis during UTO we find AngII, TGF- $\beta 1$, members of the TNF cytokine superfamily, oxidative stress, ATP depletion and mechanical stretch itself. ${ }^{60}$ AngII may induce tubular cell apoptosis through generation of TGF- $\beta 1$, reactive oxygen species (ROS) and increased expression of the lethal cytokine Fas ligand (FasL) and the lethal receptor Fas. TGF- $\beta 1$ promotes tubular apoptosis by a p38 MAP kinase-dependent mechanism. ${ }^{32,61}$ The expression of both Fas and FasL is increased in obstructed kidneys. ${ }^{60}$ Fas belongs to the TNF $\alpha$ family of receptors and is activated when cross-linked by the membrane protein FasL, a major effector of cytotoxic $\mathrm{T}$ lymphocytes and natural killer cells that is also expressed by stressed tubular cells. ${ }^{62-64}$ Infiltration of inflammatory cells may contribute to cell death by producing lethal cytokines. ${ }^{60,63-65}$ Stretching of human tubular cells increases their susceptibility to lethal stimuli such as TNF $\alpha .{ }^{66}$ Increased generation of ROS is the result of AngII or cytokine stimulation. Superoxide anion, $\mathrm{OH}^{-}$, peroxynitrite, and $\mathrm{H}_{2} \mathrm{O}_{2}$ may cause direct cellular damage by membrane peroxidation or may promote cell injury through modulation of intracellular signaling pathways. On the other hand, chronic hypoxia induced by a compromised interstitial blood flow could result in cellular ATP deprivation that might also serve as an apoptosis trigger. ${ }^{67,68}$ Contrary to other inflammatory settings, endogenous NO production as a consequence of inducible nitric oxide synthase (iNOS) appears to confer protection from stretch-induced tubular apoptosis in UUO ${ }^{69}$ Finally, changes in the extracellular matrix (ECM) related to fibrosis adversely affect tubular cell survival. ${ }^{56}$ 


\section{Tubulointerstitial fibrosis}

Progressive interstitial fibrosis is the most dramatic consequence of chronic obstructive nephropathy, and is the final common pathway of all forms of CKD. Fibrosis is characterized by increased numbers of activated fibroblasts and diffuse accumulation of ECM components such as collagen types I, III, and IV, proteoglycans and fibronectin. Gene expression changes related to fibroblast activation, epithelialmesenchymal transition (EMT) and ECM accumulation occur from day 3 of obstruction. An increased interstitial fibroblast population is evidently observed from day 7 of UUO and at day 14 a significant portion of the obstructed kidney is composed of fibroblasts and macrophages.

ECM accumulation is the end-result of increased ECM component secretion, decreased ECM degradation and increased ECM deposition. Interstitial cells in the kidney are a heterogeneous population that includes fibroblasts, dendritic cells and lymphocyte-like cells. Long-term activation of interstitial fibroblasts results in proliferation and excessive ECM accumulation. Activated fibroblasts and myofibroblasts, cells that have the appearance of fibroblasts but express $\alpha$-smooth muscle actin ( $\alpha$-SMA), have a key role in the genesis of interstitial fibrosis during ureteral obstruction..$^{70}$ The number of interstitial myofibroblasts correlates closely with the severity of tubulointerstitial fibrosis and the progression of renal failure. ${ }^{71}$ The activated fibroblasts and myofibroblasts involved in renal fibrosis originate from several sources. ${ }^{70,72}$ Controversy exists about the precise contribution of each source to the final myofibroblast population. Activated resident fibroblasts, tubular epithelial cells undergoing EMT, pericytes and perivascular fibroblast as well as circulating fibrocytes contribute to the increased fibroblast number. ${ }^{70,73-76}$ EMT is characterized by the disruption of epithelial junctions and the subsequent loss of cell polarity. ${ }^{77}$ These events are accompanied by the downregulation of epithelial marker proteins such as e-cadherin, zonula occludens-1 (ZO-1) and cytokeratin, and upregulation of mesenchymal markers including vimentin, $\alpha$-SMA and fibroblasts specific protein-1 (FSP-1).$^{70}$ The cell acquires the capacity to degrade the basement membrane and migrate from the tubular to the interstitial space, where its final myofibroblast morphology develops. In addition, chemokines secreted by infiltrating leukocytes may activate myofibroblasts. ${ }^{78}$

Understanding how and the number of fibroblasts generated may have therapeutic implications. The main known regulators of interstitial fibrosis in UTO are AngII, TGF- $\beta 1$, connective tissue growth factor (CTGF), bone morphogenetic protein-7 (BMP-7), CCL-21 and the plasminogen-plasmin axis.
AngII has direct effects in the fibrotic process, promoting EMT and recruiting other mediators such as TGF- $\beta 1 .{ }^{79,80}$ Genetic studies ascribe to angiotensin-dependent pathways about $50 \%$ of fibrosis resulting from UUO.$^{81}$ TGF- $\beta 1$, the most studied fibrogenic protein, is increased after UUO, and promotes fibroblasts activation to myofibroblasts, fibroblast proliferation, EMT, ECM production and reduces ECM degradation..$^{54,82-85}$ Activation of Smad transcription factors is the major signaling pathway for TGF- $\beta 1$. The SMAD proteins are homologs of both the drosophila protein, mothers against decapentaplegic (MAD) and the Caenorhabditis elegans protein SMA. The name is a combination of the two. The Smad family includes different proteins which form phosphorylation-dependent complexes, and move to the nucleus in response to TGF ligands to transcribe TGF-dependent genes. There are three classes of Smad: receptor-regulated, signal mediators and inhibitory Smads. Following UUO in mice, nuclear phosphorylated Smad2 and Smad3 (receptor-regulated Smads) are increased, while Smad7 (inhibitory Smad) levels are decreased as a result of accelerated degradation and ubiquitination. ${ }^{86}$ TGF- $\beta 1$ may recruit secondary effectors, such as platelet-derived growth factor (PDGF) and connective tissue growth factor (CTGF), whose expression is increased in the obstructed kidney. ${ }^{87,88}$ Fibrocytes, blood-borne cells that share markers of leukocytes as well as mesenchymal cells are attracted to the UUO kidney by locally secreted CCL21 chemokine that interacts with their CCR7 receptor. ${ }^{74}$

The plasminogen-plasmin axis has an important role in ECM turnover. In UUO plasminogen is activated to the enzyme plasmin, which activates several matrixmetalloproteinases. ${ }^{89}$ Both plasminogen activator inhibitor-1 (PAI-1) and tissue-type plasminogen activator (tPA) are upregulated in rat kidneys following UUO, indicating activation of regulatory and contraregulatory molecules. ${ }^{90}$

Bone morphogenetic protein-7 (BMP-7), also known as osteogenic protein-1 (OP-1), is a member of the TGF- $\beta 1$ superfamily that counteracts some Smad-dependent TGF- $\beta 1$ effects and is downregulated in the obstructed kidney. ${ }^{91}$ BMP-7 activates Smad1/5/8 whereas TGF- $\beta 1$ activates Smad2/3. These Smads compete for and have opposing effects on some gene targets. For example, while TGF- $\beta 1$ directly inhibits E-cadherin expression and induces EMT in a Smad3dependent manner, BMP-7 enhances E-cadherin expression via Smad5 and restores the epithelial phenotype. ${ }^{92,93}$

$\mathrm{NO}$ also modulates ECM synthesis in vitro and in vivo. ${ }^{94,95}$ In the UUO context the presence of endogenous NO protects against fibrosis. ${ }^{96,97}$ 


\section{Molecular regulation of tissue injury in obstructive renal injury: potential therapeutic targets}

Functional studies in animal models of UUO have unraveled which, among the various mediators whose local expression changes during UTO, may be potential therapeutic targets (Table 1). A variety of tools have been employed in these studies, including small molecules, cytokine administration, neutralizing antibodies, genetically modified animals and oligodeoxynucleotides (ODNs).

Many studies have focused on AngII and TGF- $\beta 1$ because of their known actions on inflammation, apoptosis and fibrosis. These approaches have shown the complexity of the regulation of tubulointerstitial fibrosis, involving a large number of closely functionally related molecules, and revealing unexpected and contradictory roles for some molecules..$^{98}$

\section{Renin-angiotensin system (RAS)}

Angiotensinogen cleavage by renin yields angiotensin I (AngI), which, in turn, is cleaved by angiotensin-converting enzyme (ACE) to generate angiotensin II (AngII), the major bioactive product of the RAS (Figure 1). ${ }^{99}$ Ang II regulates cell proliferation, apoptosis, fibrosis and the inflammatory response through the activation of AT1 and AT2 receptors. ${ }^{100,101}$ Angiotensin converting enzyme (ACE) inhibitors and Ang II receptor blockers (ARB), targeting AT1, are commonly prescribed anti-hypertensive drugs clinically in use for renoprotection. CKD is characterized histologically by glomerular sclerosis, tubular atrophy and interstitial inflammation, and, thus, shares features with UTO. Ang II has long been known as a key player on the functional (glomerular hyperfiltration) and histological changes occurring in CKD. Thus, the inhibition of the RAS plays a pivotal role on the treatment of CKD of different causes, particularly when proteinuria is present. ${ }^{102-108}$

Inhibition of RAS ameliorates tubulointerstitial fibrosis and arrests the inflammatory process in experimental models of complete UUO on adult rats. ${ }^{26-30}$ Moreover, ACE inhibition or AT1-receptor inhibition initiated after weaning significantly improve renal function in rats subjected to neonatal partial UUO. ${ }^{109,110}$ However, inhibition of Ang II in adult rats with partial UTO can aggravate hydronephrosis and decrease the ureteral peristaltic activity. ${ }^{111}$ Ang II inhibition can also worsen injury to the partially obstructed kidney in neonatal rats during renal maturation, even after completion of nephrogenesis. ${ }^{112,113}$ In children, ACE inhibitors reduce urinary washout in partially obstructed hydronephrotic kidneys, as assessed by diuretic renography. ${ }^{114}$ Additionally, use of ACE inhibitors in pregnancy is widely known to result on serious malformations on the urinary tract and on the cardiovascular and central nervous systems. ${ }^{115-119}$

Studies using knockout mice or specific antagonists of AT1 (as losartan) or AT2 (PD123319) receptors have demonstrated that both receptors modulate kidney disease progression in the UUO model. ${ }^{26,43,48,120-122}$ In this model, AT1 antagonists did not diminish inflammatory cell infiltration and VCAM-1 expression. ${ }^{48}$ At day 4, obstructed kidneys of AT1 knockout mice presented the same gene upregulation and inflammatory cell infiltration than WT, and after 7 days, similar renal injury. ${ }^{30}$ By contrast, upon UUO AT2 null mutant mice have a more extensive and severe fibrosis compared with WT animals. ${ }^{122}$ In wild type (WT) mice, only ACE inhibition or combined therapy with AT1 plus AT2 antagonists blocked renal monocyte infiltration, NF- $\kappa B$ activation, and upregulation of NF- $\mathrm{KB}$-related proinflammatory genes. ${ }^{30}$ These data suggest that the blockade of Ang II generation or both AT1 and AT2 receptors is necessary to prevent the inflammatory process. ${ }^{30}$ AT1 antagonism ameliorated tubular atrophy and fibrosis on rat obstructed kidneys, and downregulated profibrotic factors like CTGF. ${ }^{26}$ Direct inhibition of ACE in a rat UUO model reduced monocyte/macrophage infiltration and ECM proteins accumulation. ${ }^{123}$

It is interesting that in WT mice, the ACE inhibitorinduced reduction of TNF $\alpha$ and MCP-1 gene expression is higher than that achieved by combined AT1 and AT2 blockade. These data suggest a role for AngII-derived peptides, whose production is inhibited by ACE inhibitors, and that may be increased by the availability of AngII following AT1/2 blockade (Figure 1). Besides AngII, other Ang peptides, such as AngIV [Ang-(3-8)] and Ang-(1-7) may also have important biological activities (Figure 1). ${ }^{124}$ In vascular smooth muscle cells, Ang IV binds to the AT4 receptor, activates NF- $\mathrm{KB}$ and increases $\mathrm{MCP}-1 .{ }^{125}$ In the kidney Ang-(1-7) has AT1/AT2-independent inflammatory properties: it binds to the Mas receptor, activates NF- $\mathrm{KB}$ and promotes the secretion of NF- $\mathrm{kB}$-dependent proinflammatory molecules. In this regard, UUO Mas knockout mice had decreased perivascular interstitial mononuclear cell infiltrates, tubular damage and interstitial fibrosis when compared with wild-type UUO. ${ }^{126}$

The RAS interacts with other players in renal injury: blocking the TNF $\alpha$ system (double knockout mice for TNF $\alpha$ receptors TNFR1 and TNFR2) or treatment with an ACE inhibitor leads to partial blunting of fibrosis, whereas 
Table I Potential therapeutic targets in obstructive nephropathy

\begin{tabular}{|c|c|c|c|}
\hline Molecule & Targeting technique & Effect & Ref \\
\hline \multicolumn{4}{|l|}{ RAS system } \\
\hline \multirow[t]{2}{*}{ ATI } & receptor antagonist & $\begin{array}{l}\text { Combination with AT2 antagonist } \\
\text { decreased inflammation }\end{array}$ & 30 \\
\hline & KO & no effect & \\
\hline \multirow[t]{2}{*}{ AT2 } & receptor antagonist & $\begin{array}{l}\text { Combination with ATI antagonist } \\
\text { decreased inflammation }\end{array}$ & 30 \\
\hline & KO & Increased fibrosis & 122 \\
\hline Kinin $\mathrm{BI}$ receptor & receptor antagonist & Decreased inflammation and fibrosis & 151 \\
\hline MAS (Ang-(I-7) receptor) & KO & Decreased inflammation and fibrosis & 126 \\
\hline ACE & pharmacological inhibition & Decreased inflammation and fibrosis & 123 \\
\hline \multicolumn{4}{|l|}{ Inflammation } \\
\hline \multirow[t]{2}{*}{ NFKB } & $\begin{array}{l}\text { NF- } \mathrm{KB} \text { decoy double-stranded } \\
\text { ODN }\end{array}$ & Decreased NFKB activation and inflammation & 148 \\
\hline & pharmacological inhibition & $\begin{array}{l}\text { DHMEQ, PDCT and parthenolide decrease } \\
\text { inflammation and fibrosis }\end{array}$ & 30,147 \\
\hline TNF $\alpha$ receptors I and 2 & KO & Decreased inflammation & 127 \\
\hline TNF $\alpha$ & antibody neutralization & Decreased NFKB activation and inflammation & 149 \\
\hline \multirow[t]{2}{*}{ CCR2 and CCRI } & pharmacological inhibition & Decreased inflammation and fibrosis & $152,154,155$ \\
\hline & KO & Decreased inflammation and fibrosis & $152,154,155$ \\
\hline OPN & KO & Decreased inflammation & 156 \\
\hline MCSF-I & receptor antagonist & Decreased inflammation & 51 \\
\hline CCL2I/CCR7 & $\begin{array}{l}\text { CCL2I antibody neutralization } \\
\text { CCR7 KO }\end{array}$ & Decreased fibrosis and inflammation & 74 \\
\hline \multicolumn{4}{|l|}{ TGF- $\beta$ I } \\
\hline TGF- $\beta$ I & antibody neutralization & Decreased apoptosis & 129 \\
\hline BMP-7 & administration & Decreased inflammation and may decrease fibrosis & 91 \\
\hline Decorin & KO & Increased tubular apoptosis and atrophy & 135 \\
\hline \multirow[t]{2}{*}{ Smad3 } & KO & Decreased fibrosis, inflammation, and apoptosis & 133 \\
\hline & KO & Decreased fibrosis (decreased EMT and ECM) & 132 \\
\hline Smad7 & transgenic mice overexpression & Decreased inflammation and NFKB inhibition & 134 \\
\hline EPO & administration & Decreased fibrosis (decreased EMT) & \\
\hline \multicolumn{4}{|c|}{ Plasminogen/plasmin system } \\
\hline tPA & KO & $\begin{array}{l}\text { Decreased EMT, preservation of the } \\
\text { integrity of tubular basement membranes }\end{array}$ & 142 \\
\hline \multirow[t]{2}{*}{ PAI-I } & transgenic mice overexpression & Increased inflammation and fibrosis & 143 \\
\hline & KO & Decreased inflammation and fibrosis & 144 \\
\hline \multicolumn{4}{|l|}{ Other } \\
\hline ET-I & receptor antagonist & $\begin{array}{l}\text { Decreased tubular apoptosis, } \\
\text { restoration of blood flow }\end{array}$ & 31 \\
\hline \multirow[t]{2}{*}{ PTHrP } & transgenic mice overexpression & Increased inflammation & 150 \\
\hline & receptor antagonist & Decreased inflammation & \\
\hline CDK & pharmacological inhibition & Decreased tubular cell proliferation and apoptosis & 158 \\
\hline \multirow[t]{3}{*}{ iNOS } & KO & Conflict results & \\
\hline & & Increased inflammation and fibrosis & 96 \\
\hline & & Decreased fibrosis (through other NOS isoforms) & $|4|$ \\
\hline L-arginine & administration & Decreased fibrosis (Induces NO) & 139 \\
\hline
\end{tabular}

Notes: Bolded text in Effect column = interventions with negative consequences.

Abbreviations: KO, knock-out; TNF, tumor necrosis factor; ACE, angiotensin-converting enzyme; NF- $\mathrm{KB}$, nuclear transcription factor-kappaB; OPN, osteopontin; MCSF-I, macrophage colony-stimulating factor-I; TGF- $\beta$ I, transforming growth factor- $\beta$ I; BMP-7, bone morphogenetic protein-7; EPO, erythropoietin; PAI-I, plasminogen activator; inhibitor-I; RAS, renin-angiotensin-aldosterone system; ET-I, endothelin-I; PTHrP, parathyroid hormone-related protein; iNOS, inducible nitric oxide synthase. 


\section{Angiotensinogen}

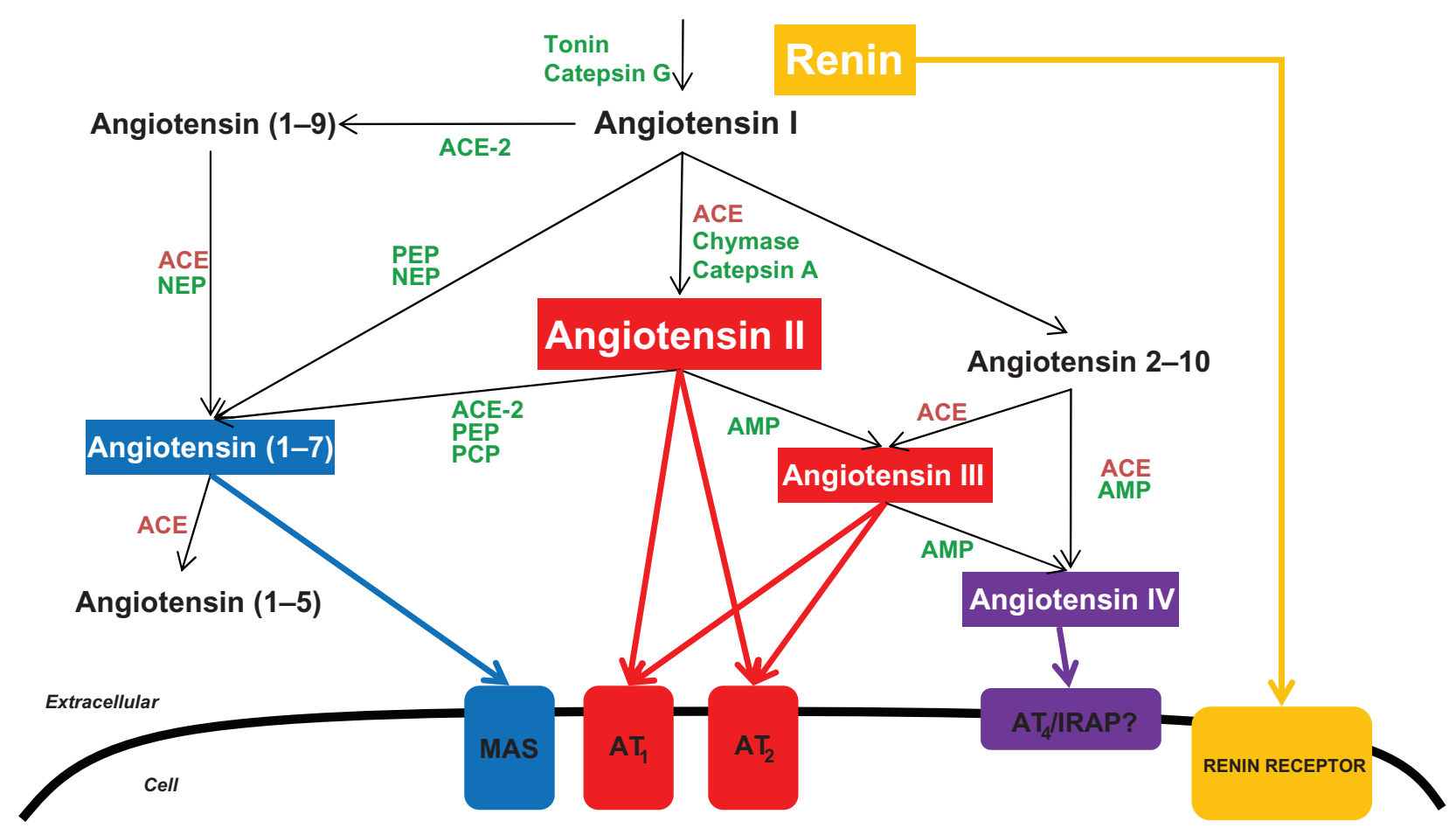

Figure I Schematic representation of the enzymatic pathways involved in the generation of angiotensin peptides.

Abbreviations: ACE, angiotensin-converting enzyme; AMP, aminopeptidase; ATI, Ang II type I receptor;AT2, Ang II type 2 receptor; AT4,Ang IV receptor; MAS, Ang-(I-7) receptor; IRAP, insulin-regulated aminopeptidase; PCP, prolyl-carboxypeptidase; PEP, prolyl-endopeptidase; NEP, neutral-endopeptidase.

blocking both AngII and TNF $\alpha$ systems further inhibited interstitial fibrosis and tubule atrophy in UUO. ${ }^{127}$

The different responses to Ang II targeting in experimental models and the lack of clinical trials on UTO create a gap for the clinical use of ACE inhibitors and angiotensin receptor blockers (ARBs) in this setting. Indeed, patients with UTO are usually excluded from clinical trials of these drugs in CKD. ${ }^{106,128}$ Additional studies will thus be required to establish the optimal clinical indications for Ang II targeting in UTO.

\section{Other pathways}

Additional functional studies have targeted TGF- $\beta 1$ and Smad, other profibrotic molecules and inflammation-related pathways, including NF- $\kappa \mathrm{B}$.

The blockade of TGF- $\beta 1$ with neutralizing antibodies markedly reduced apoptosis as well as protein overexpression of ECM components (Type III Collagen and Fibronectin) in a rat UUO model ${ }^{129}$ as observed in cultured renal cells..$^{130,131}$ The antifibrotic potential of anti-TGF- $\beta 1$ antibodies is undergoing a clinical trial in the renal glomerular fibrosis and podocyte loss of focal segmental glomerular sclerosis (ClinicalTrials. gov Identifier: NCT00464321). Smad3-null mice with UUO did not upregulate TGF- $\beta 1$ and the EMT process, and displayed reduced interstitial fibrosis. ${ }^{132}$ These results were confirmed in another independent Smad3 knockout mice UUO model that showed attenuation of renal fibrosis, inflammation, and apoptosis when compared to wild type UUO. ${ }^{133}$ By contrast, UUO transgenic mice overexpressing Smad7 had around $70 \%$ less interstitial fibroblasts and renal ECM accumulation. ${ }^{134}$ Further supporting a role for TGF- $\beta 1$, in mice with UUO targeted deletion of decorin, a proteoglycan that counters the actions of TGF- $\beta 1$, increases tubular apoptosis and tubular atrophy. ${ }^{135}$ Therapy with BMP-7 in rats protects against UUO-induced renal injury by inhibiting inflammation and EMT and preserving tubular epithelial integrity. These beneficial effects were greater than that obtained with the ACE inhibitor enalapril, ${ }^{91}$ Despite these results, BMP-7 failed to attenuate TGF- $\beta 1$-induced EMT in vitro. ${ }^{136}$ Recombinant human erythropoietin (EPO) in a mice model of ureteral obstruction inhibited the progression of renal fibrosis, partly through the reduction of TGF- $\beta 1$-induced EMT. ${ }^{137}$

Another key mediator in UUO is NO. NO is synthesized from L-arginine via the enzyme NO synthase (NOS), which exists in three forms: neuronal NOS (nNOS) and endothelial NOS (eNOS), which are constitutively expressed, and there is an inducible isoform (iNOS). During ureteral obstruction, endogenous NO protects the kidney through the inhibition 


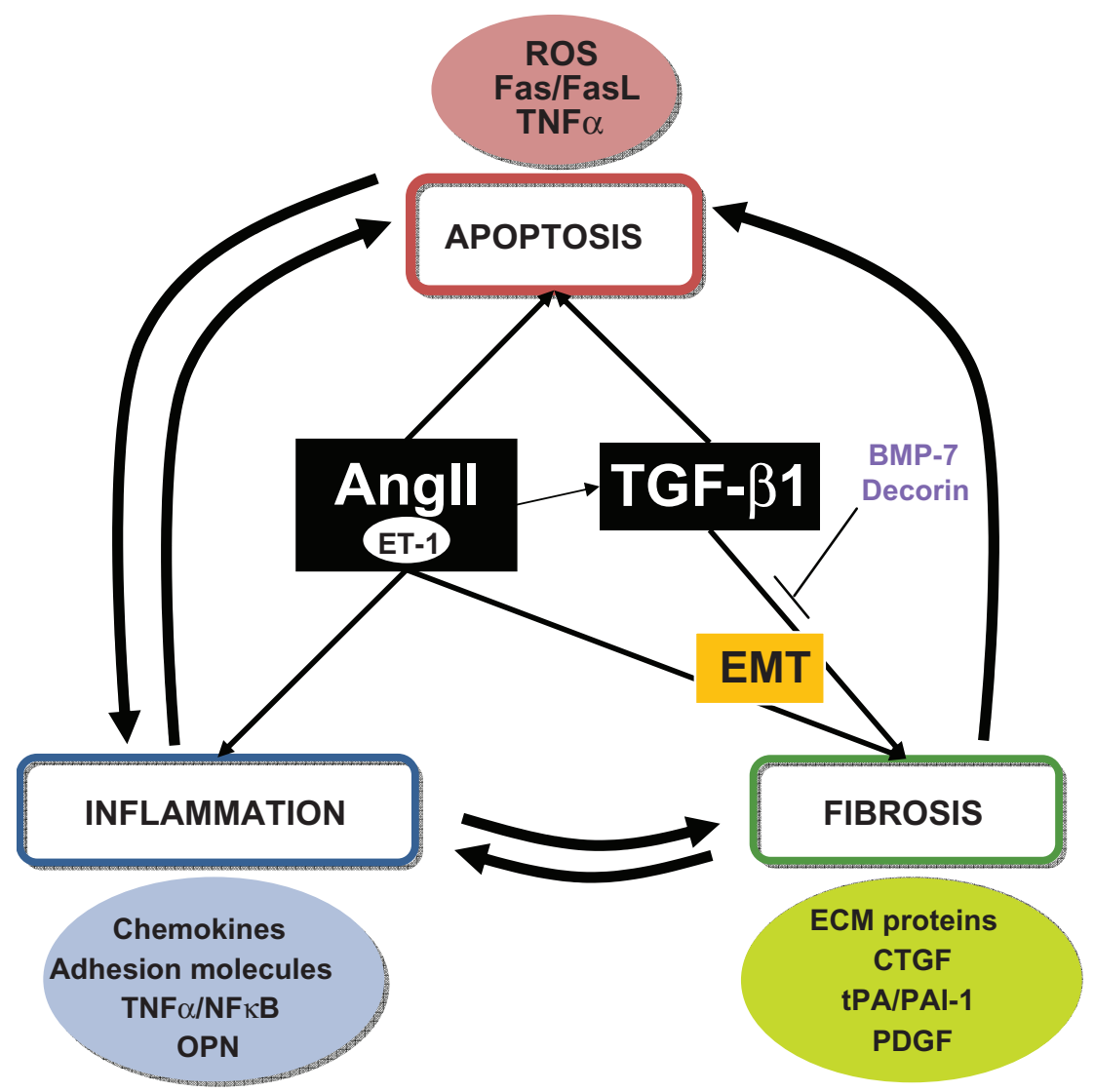

Figure 2 Unilateral ureteral obstruction (UUO) processes and molecules. Representation of interconnections between the different processes in UUO and the main molecules involved.

of excessive vasoconstriction triggered by the RAS system, reduces macrophage infiltration, apoptosis and ECM accumulation. ${ }^{34,96,138,139}$ Arginine, a direct precursor to NO, blunts the fibrosis response in a rat model of ureteral obstruction. ${ }^{139}$ Following UUO, iNOS is upregulated mainly in the kidney medulla, whereas constitutive NOS are more upregulated in the cortex. ${ }^{140}$ Targeted deletion of the iNOS gene (iNOS knockout mice) exacerbates interstitial fibrosis. ${ }^{96}$ However, there is also evidence for the participation of constitutive NOS in tissue injury in UUO. ${ }^{141}$

One promising target, directly involved in ECM accumulation, is the tPA and PAI-1 system. Targeted deletion of tPA blocks EMT and reduces the activity of matrix metalloproteinase-9 (MMP-9), preserving the integrity of tubular basement membranes in mice with UUO, ${ }^{142}$ suggesting that plasminogen activation may be a therapeutic target. However, the pathophysiological role of the system is more complex than previously thought, and inhibiting this pathways by overexpressing PAI-1 increased macrophage recruitment, myofibroblast transformation and collagen I mRNA in mice UUO model. ${ }^{143}$ Targeted deletion of PAI- 1 reduces macrophage infiltration, myofibroblast transformation and interstitial fibrosis in mice with UUO. ${ }^{144}$ Blocking PAI-1 function has shown particular capacity in preventing or reversing fibrosis in various models of progressive renal disease, but it is likely that multiple pathways will need to be inhibited to have a significant impact. ${ }^{145,146}$

$\mathrm{NF}-\kappa \mathrm{B}$ has a key role in inflammation. Pharmacological inhibition of NF- $\kappa \mathrm{B}$ activation with dehydroxymethylepoxyquinomicin (DHMEQ), pyrrolidine-dithiocarbamate (PDCT) or parthenolide reduced the presence of inflammatory cells (macrophages, $\mathrm{T}$ cells, etc), the upregulation of chemokines and cytokines and finally, ameliorated renal damage in the obstructed kidneys of mice. ${ }^{30,147}$ However, these molecules are not completely specific for NF- $\kappa \mathrm{B}$. A stable ring type NF- $\kappa \mathrm{B}$ decoy double-stranded oligode-

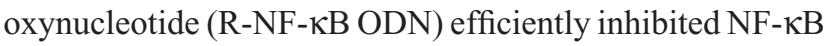
activity in vitro, and in vivo in a mouse UUO model resulting in a decreased expression of TNF $\alpha$, IL- $1 \beta$, TGF- $\beta 1$ and ECM proteins such as fibronectin. ${ }^{148}$ TNF $\alpha$ neutralization has inhibited NF- $\mathrm{KB}$ activation in rat UUO. ${ }^{149}$

In other mouse UUO models, anti-c-fms (antibody to receptor of MCSF-1) treatment slightly decreased monocyte recruitment at day 1 , but reduced macrophage accumulation 
by $75 \%$ at day $10 .{ }^{51}$ Parathyroid hormone-related protein (PTHrP) also contributes to UUO-induced renal injury. ${ }^{150}$ Transgenic mice overexpressing PTHrP had exacerbated inflammation upon UUO. Losartan ( $\mathrm{AT}_{2}$ antagonist) and PTHrP receptor 1 antagonist reduced inflammation after ureter obstruction of these transgenic mice, suggesting that PTHrP could recapitulate some proinflammatory actions of AngII. PTHrP increased inflammation through activation of the extracellular signal-regulated kinase (ERK)/NF- $\kappa \mathrm{B}$ pathway. Any reversal of PTHrP constitutive overexpression in these transgenic mice decreased this inflammatory response. The proinflammatory kinin $\mathrm{B} 1$ receptor $(\mathrm{B} 1 \mathrm{R})$ is overexpressed in mouse UUO and post-treatment with an orally active nonpeptide B1R antagonist blocks macrophage infiltration, reversing renal fibrosis. ${ }^{151}$

Targeted deletion of the CCR2 gene or administration of CCR2 inhibitors reduces macrophage infiltration and interstitial fibrosis following UUO in mice. ${ }^{152,153}$ Similarly, deletion or inhibition of the CCR1 receptor attenuates leukocyte recruitment following UUO. ${ }^{154,155}$ Macrophage influx was reduced in OPN knockout mice compared to wild type mice in early stage (day 4 and day 7), but not in later stage (day 14) of UUO nephropathy. ${ }^{156}$ In mice, the blockade of CCL21/CCR7 signaling by anti-CCL21 antibodies or CCR7 deficiency reduced macrophage infiltration, MCP-1/ CCL 2 and TGF- $\beta 1$ expression, and renal fibrosis after ureteral obstruction. ${ }^{74}$ The obstructed kidney tries to adapt by expressing protective molecules, such as hemoxygenase-1 (HO-1). Overexpression of HO-1 confers marked resistance to apoptotic stimuli. ${ }^{157}$ A further maladaptive response might be tubular cell proliferation. The cyclin-dependent kinase inhibitor p27Kip1 limits tubular cell proliferation and apoptosis following UUO in mice. ${ }^{158}$ Other potential target is ET-1 that has a key role in vasoconstriction during UUO. Pretreatment with the ET-1 receptor dual antagonist, bosentan, reduced by $60 \%$ apoptotic cells in the UUO rat model compared with untreated group, and almost restored the normal blood flow. ${ }^{31}$

\section{Molecular tools for clinical outcome prediction}

Availability of a biomarker constitutes an urgent need for the diagnosis and management of UTO, especially in newborns and infants where the clinical significance of obstruction constitutes the main issue, dictating the need for surgery or a conservative approach. This is further complicated by the invasive and repetitive tests needed for the surveillance of this condition and the possible induction of irreversible kidney lesions by temporary UTO. ${ }^{159,160}$ A non-invasive biomarker may provide information on the degree of injury and functional impairment as well as prognostic information. ${ }^{159,161}$

Until recently the search for a biomarker was based on the identification of several key molecules for the pathogenesis of UTO in animal models and their subsequent investigation in clinical studies. This approach allowed the identification of several promising molecules potentially useful for clinical prediction of the prognosis of UTO, ${ }^{161}$ namely TGF- $\beta 1$, MCP-1, EGF, ET-1 and tubular enzymes.

TGF- $\beta 1$ is increased in kidney tissue, ${ }^{162}$ in the stenotic ureter $^{163}$ and in urine ${ }^{164-167}$ from children with UPJ obstruction, allowing the diagnosis with good accuracy values (for a threshold of $190 \mathrm{pg} / \mathrm{mg}$ creatinine) for UPJ obstruction requiring surgery (Table 2). ${ }^{167}$ However increased TGF- $\beta 1$ is not specific for UTO as it can also be found on other renal diseases. ${ }^{168-171}$ MCP-1, a chemokine, and endothelin-1, a vasoactive protein with proinflammatory properties, are also upregulated in tissue and urine of children with UPJ obstruction. ${ }^{172-174}$ The urinary level of endothelin-1 had a sensitivity of $74.3 \%$, a specificity of $90 \%$, and an overall accuracy of $81.5 \%$, for a cut-off value of $3 \mathrm{fmol} / \mathrm{mg}$ creatinine, allowing the identification of UPJ obstruction requiring surgery (Table 2). ${ }^{175}$ Epidermal growth factor (EGF), a growth factor with proliferative and pro-survival properties for tubular cells, on the other hand, was reduced in children with UPJ obstruction. ${ }^{162,163,173,174}$ However, subsequent studies did not confirm decreased urinary EGF in subjects with UTO, thus reducing its biomarker potential. ${ }^{167,176}$

Urinary tubular enzymes, such as N-acetyl-beta-Dglucosaminidase (NAG), gamma-glutamyl transferase (GGT) and alkaline phosphatase (AP) have been evaluated for diagnostic and prognostic value in clinical UTO. ${ }^{177-179}$ The combination of NAG and AP was reported to have a sensitivity of $100 \%$, a specificity of $80 \%$ and an overall accuracy of $94 \%$ for differentiating between children with ureteropelvic junction obstruction requiring pyeloplasty and those with dilated nonobstructed kidneys suitable for conservative treatment (Table 2). ${ }^{179}$ However urinary tubular enzymes are nonspecific markers of tubular injury and are elevated in other renal diseases. ${ }^{180}$

Interestingly, most of these urinary biomarkers take several months to regress to normal values after pyeloplasty, reflecting the fact that the initial obstruction sets in motion local, self-sustained inflammatory and tissue repair events. ${ }^{167,175,179}$

An alternative approach involves large-scale unbiased gene expression profiling using transcriptomic array techniques or unbiased urine proteomic profiling. These tech- 


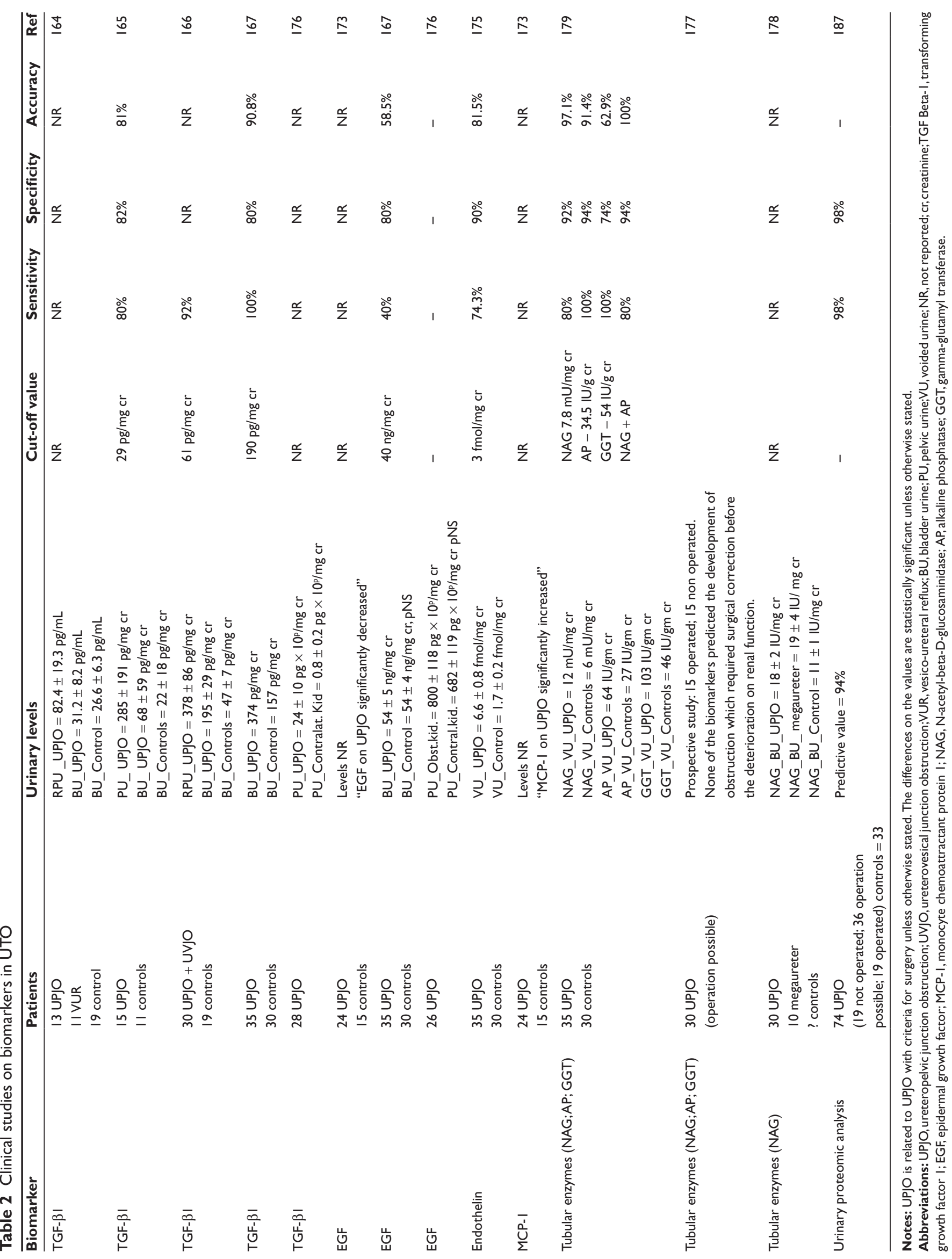


niques are not based on prior physiopathological knowledge. Rather they screen the level of expression or concentration of thousands of genes or peptides/proteins, looking for patterns that may help in making a diagnosis or predicting a prognosis. ${ }^{181}$ In addition, these techniques may identify novel pathophysiological networks not previously suspected from information generated by traditional approaches. Transcriptomics has uncovered new molecules with the potential to become biomarkers in UTO. ${ }^{182-185}$ However, they have not yet been explored in clinical studies. The emergence of proteomics has made possible the full analysis of a large range of proteins and peptides on different biological samples. Its application to UTO has allowed the discovery of new molecules involved on its pathogenesis ${ }^{186}$ as well as specific and sensitive biomarkers. ${ }^{187}$ The analysis of 51 urinary polypeptides by proteomic techniques allowed the discrimination between infants with several severity degrees of UPJ obstruction that would benefit from surgical correction with a sensitivity and specificity of $98 \%$ and a predictive value of $94 \% .{ }^{187}$ Future studies should focus on the potential of biomarkers of individual peptides that may be assayed by more conventional techniques; as proteomics is not routinely available for diagnosis in most clinical laboratories. A recent European initiative, EUROKUP, has, among other aims, to establish homogeneous sampling and processing techniques that would facilitate the clinical use of urine proteomics. ${ }^{188}$

\section{Conclusions}

The main treatment of UTO is to relieve the obstruction. However, under some circumstances the precise timing of the intervention is not unclear. The mechanical UTO sets in motion a series of molecularly mediated events that lead to tubular cell death, interstitial inflammation and fibrosis. These events may provide a molecular signature of a damaged kidney that may be used for biomarker-based diagnosis and indicators of therapy. In addition, these molecules may be therapeutic targets that may limit renal injury when removing the obstruction must be delayed.

\section{Acknowledgments}

Grant support: FIS PI06/0046, PI081564, PS09/00447, ISCIII-RETIC, REDinREN/RD06/0003, REDinREN/ RD06/0004, EUproject, PCI Iberoamérica A/9571/07. DIALOK: LSHB-CT-2007-036644 Comunidad de Madrid/ FRACM/S-BIO0283/2006, Salary support: FIS to ABM, AMR, BS, Fundacion Conchita Rabago to ACU and SB, Programa Intensificación Actividad Investigadora (ISCIII/ Agencia Laín-Entralgo/CM) to AO.

\section{Disclosures}

The authors report no conflicts of interest relevant to this review.

\section{References}

1. Thomas D. Fetal uropathy. Br J Urol. 1990;66(3):225-231.

2. NAPRTCS. North American Pediatric Renal Trials and Collaborative Studies, 2008 Annual Report. Rockville, MD, EMMES2008.

3. Lewis M, Shaw J, Reid C, Evans J, Webb N, Verrier-Jones K. Demography and management of childhood established renal failure in the UK (chapter 13). Nephrol Dial Transplant. 2007;22 Suppl 7:vii165-vii175.

4. Kaufman J, Dhakal M, Patel B, Hamburger R. Community-acquired acute renal failure. Am J Kidney Dis. 1991:17(2):191-198.

5. Sacks S, Aparicio S, Bevan A, Oliver D, Will E, Davison A. Late renal failure due to prostatic outflow obstruction: a preventable disease. $B M J$. 1989;298(6667):156-159.

6. USRDS. United States Renal Data System, 2005 Annual Data report: Atlas of end stage renal disease in the United States. Bethesda, MD, National Institutes of Health, National Institute of Diabetes and Digestive and Kidney Diseases. 2005.

7. Woodward M, Frank D. Postnatal management of antenatal hydronephrosis. BJU Int. 2002;89(2):149-156.

8. Chevalier R. Perinatal obstructive nephropathy. Semin Perinatol. 2004;28(2):124-131.

9. Ravanan R, Tomson C. Natural history of postobstructive nephropathy: a single-center retrospective study. Nephron Clin Pract. 2007;105(4): c165-c170.

10. Abou El-Ghar M, Shokeir A, Refaie H, El-Diasty T. MRI in patients with chronic obstructive uropathy and compromised renal function: a sole method for morphological and functional assessment. Br J Radiol. 2008;81(968):624-629.

11. Better O, Arieff A, Massry S, Kleeman C, Maxwell M. Studies on renal function after relief of complete unilateral ureteral obstruction of three months' duration in man. Am J Med. 1973;54(2):234-240.

12. Chevalier R. Obstructive nephropathy and the developing kidney: too little or too much angiotensin? Kidney Int. 2004;65(4):1517-1518.

13. Vanderheyden T, Kumar S, Fisk N. Fetal renal impairment. Semin Neonatol. 2003;8(4):279-289.

14. Yohannes $P$, Hanna M. Current trends in the management of posterior urethral valves in the pediatric population. Urology. 2002;60(6):947-953.

15. Chevalier R. Obstructive nephropathy: towards biomarker discovery and gene therapy. Nat Clin Pract Nephrol. 2006;2(3):157-168.

16. Klahr S. Obstructive nephropathy. Intern Med. 2000;39(5):355-361.

17. Selkurt E, Deetjen P, Brechtelsbauer H. Tubular pressure gradients and filtration dynamics during urinary stop flow in the rat. Pflugers Arch Gesamte Physiol Menschen Tiere. 1965;286(1):19-35.

18. Klahr S. Pathophysiology of obstructive nephropathy: a 1991 update. Semin Nephrol. 1991;11(2):156-168.

19. Jaenike J. The renal response to ureteral obstruction: a model for the study of factors which influence glomerular filtration pressure. $J$ Lab Clin Med. 1970;76(3):373-382.

20. Tanner G, Knopp L. Glomerular blood flow after single nephron obstruction in the rat kidney. Am J Physiol. 1986;250(1 Pt 2):F77-F85.

21. Idbohrn H, Muren A. Renal blood flow in experimental hydronephrosis. Acta Physiol Scand. 1956;38(2):200-206.

22. Vaughan EJ, Shenasky JN, Gillenwater J. Mechanism of acute hemodynamic response to ureteral occlusion. Invest Urol. 1971;9(2): 109-118.

23. Gaudio K, Siegel N, Hayslett J, Kashgarian M. Renal perfusion and intratubular pressure during ureteral occlusion in the rat. Am J Physiol. 1980;238(3):F205-F209.

24. Harris K, Klahr S, Schreiner G. Obstructive nephropathy: from mechanical disturbance to immune activation? Exp Nephrol. 1993;1(3): 198-204. 
25. Wen J, Frøkiaer J, Jørgensen T, Djurhuus J. Obstructive nephropathy: an update of the experimental research. Urol Res. 1999;27(1):29-39.

26. Ishidoya S, Morrissey J, McCracken R, Reyes A, Klahr S. Angiotensin II receptor antagonist ameliorates renal tubulointerstitial fibrosis caused by unilateral ureteral obstruction. Kidney Int. 1995;47(5):1285-1294.

27. Ishidoya S, Morrissey J, McCracken R, Klahr S. Delayed treatment with enalapril halts tubulointerstitial fibrosis in rats with obstructive nephropathy. Kidney Int. 1996;49(4):1110-1119.

28. Klahr S, Ishidoya S, Morrissey J. Role of angiotensin II in the tubulointerstitial fibrosis of obstructive nephropathy. Am J Kidney Dis. 1995;26(1):141-146.

29. Moridaira K, Morrissey J, Fitzgerald M, et al. ACE inhibition increases expression of the ETB receptor in kidneys of mice with unilateral obstruction. Am J Physiol Renal Physiol. 2003;284(1):F209-F217.

30. Esteban V, Lorenzo O, Rupérez M, et al. Angiotensin II, via AT1 and AT2 receptors and NF-kappaB pathway, regulates the inflammatory response in unilateral ureteral obstruction. J Am Soc Nephrol. 2004;15(6):1514-1529.

31. Hegarty N, Young L, O’Neill A, Watson R, Fitzpatrick J. Endothelin in unilateral ureteral obstruction: vascular and cellular effects. J Urol. 2003;169(2):740-744.

32. Miyajima A, Chen J, Kirman I, Poppas D, Darracott Vaughan EJ, Felsen D. Interaction of nitric oxide and transforming growth factorbeta1 induced by angiotensin II and mechanical stretch in rat renal tubular epithelial cells. J Urol. 2000;164(5):1729-1734.

33. Ricardo S, Ding G, Eufemio M, Diamond J. Antioxidant expression in experimental hydronephrosis: role of mechanical stretch and growth factors. Am J Physiol. 1997;272(6 Pt 2):F789-F798.

34. Chevalier R, Thornhill B, Gomez R. EDRF modulates renal hemodynamics during unilateral ureteral obstruction in the rat. Kidney Int. 1992;42(2):400-406.

35. Eddy A. Progression in chronic kidney disease. Adv Chronic Kidney Dis. 2005;12(4):353-365.

36. Lan H, Nikolic-Paterson D, Mu W, Atkins R. Local macrophage proliferation in the progression of glomerular and tubulointerstitial injury in rat anti-GBM glomerulonephritis. Kidney Int. 1995;48(3):753-760.

37. Diamond J, Kees-Folts D, Ricardo S, Pruznak A, Eufemio M. Early and persistent up-regulated expression of renal cortical osteopontin in experimental hydronephrosis. Am J Pathol. 1995;146(6):1455-1466.

38. Yoo K, Thornhill B, Forbes M, et al. Osteopontin regulates renal apoptosis and interstitial fibrosis in neonatal chronic unilateral ureteral obstruction. Kidney Int. 2006;70(10):1735-1741.

39. Chevalier R, Cachat F. Role of angiotensin II in chronic ureteral obstruction. Contrib Nephrol. 2001;(135):250-260.

40. Misseri R, Meldrum D, Dagher P, Hile K, Rink R, Meldrum K. Unilateral ureteral obstruction induces renal tubular cell production of tumor necrosis factor-alpha independent of inflammatory cell infiltration. J Urol. 2004;172(4 Pt 2):1595-1599.

41. Misseri R, Meldrum D, Dinarello C, et al. TNF-alpha mediates obstruction-induced renal tubular cell apoptosis and proapoptotic signaling. Am J Physiol Renal Physiol. 2005;288(2):F406-F411.

42. Morrissey J, Klahr S. Rapid communication. Enalapril decreases nuclear factor kappa B activation in the kidney with ureteral obstruction. Kidney Int. 1997;52(4):926-933.

43. Morrissey J, Klahr S. Effect of AT2 receptor blockade on the pathogenesis of renal fibrosis. Am J Physiol. 1999;276(1 Pt 2):F39-F45.

44. Li J, Brasier A. Angiotensinogen gene activation by angiotensin II is mediated by the rel A (nuclear factor-kappaB p65) transcription factor: one mechanism for the renin angiotensin system positive feedback loop in hepatocytes. Mol Endocrinol. 1996;10(3):252-264.

45. Morrissey J, Klahr S. Transcription factor NF-kappaB regulation of renal fibrosis during ureteral obstruction. Semin Nephrol. 1998;18(6): 603-611.

46. Donnahoo K, Meldrum D, Shenkar R, Chung C, Abraham E, Harken A. Early renal ischemia, with or without reperfusion, activates NFkappaB and increases TNF-alpha bioactivity in the kidney. J Urol. 2000;163(4):1328-1332.
47. Ricardo S, Levinson M, DeJoseph M, Diamond J. Expression of adhesion molecules in rat renal cortex during experimental hydronephrosis. Kidney Int. 1996;50(6):2002-2010.

48. Morrissey J, Klahr S. Differential effects of ACE and AT1 receptor inhibition on chemoattractant and adhesion molecule synthesis. Am J Physiol. 1998;274(3 Pt 2):F580-F586.

49. Vielhauer V, Anders H, Mack M, et al. Obstructive nephropathy in the mouse: progressive fibrosis correlates with tubulointerstitial chemokine expression and accumulation of $\mathrm{CC}$ chemokine receptor 2- and 5-positive leukocytes. J Am Soc Nephrol. 2001;12(6):1173-1187.

50. Weber G, Ashkar S, Glimcher M, Cantor H. Receptor-ligand interaction between CD44 and osteopontin (Eta-1). Science. 1996;271(5248):509-512.

51. Le Meur Y, Tesch G, Hill P, et al. Macrophage accumulation at a site of renal inflammation is dependent on the M-CSF/c-fms pathway. $J$ Leukoc Biol. 2002;72(3):530-537.

52. Gaboury J, Woodman R, Granger D, Reinhardt P, Kubes P. Nitric oxide prevents leukocyte adherence: role of superoxide. Am J Physiol. 1993;265(3 Pt 2):H862-H867.

53. Vodovotz Y. Control of nitric oxide production by transforming growth factor-beta1: mechanistic insights and potential relevance to human disease. Nitric Oxide. 1997;1(1):3-17.

54. Kaneto H, Ohtani H, Fukuzaki A, et al. Increased expression of TGF-beta1 but not of its receptors contributes to human obstructive nephropathy. Kidney Int. 1999;56(6):2137-2146.

55. Sanz A, Santamaría B, Ruiz-Ortega M, Egido J, Ortiz A. Mechanisms of renal apoptosis in health and disease. J Am Soc Nephrol. 2008;19(9):1634-1642.

56. Ortiz A, Justo P, Sanz A, Lorz C, Egido J. Targeting apoptosis in acute tubular injury. Biochem Pharmacol. 2003;66(8):1589-1594.

57. Gobe G, Axelsen R. Genesis of renal tubular atrophy in experimental hydronephrosis in the rat. Role of apoptosis. Lab Invest. 1987;56(3):273-281.

58. Misaki T, Yamamoto T, Suzuki S, et al. Decrease in tumor necrosis factor-alpha receptor-associated death domain results from ubiquitindependent degradation in obstructive renal injury in rats. Am J Pathol. 2009;175(1):74-83.

59. Cachat F, Lange-Sperandio B, Chang A, et al. Ureteral obstruction in neonatal mice elicits segment-specific tubular cell responses leading to nephron loss. Kidney Int. 2003;63(2):564-575.

60. Jones E, Shahed A, Shoskes D. Modulation of apoptotic and inflammatory genes by bioflavonoids and angiotensin II inhibition in ureteral obstruction. Urology. 2000;56(2):346-351.

61. Dai C, Yang J, Liu Y. Transforming growth factor-beta1 potentiates renal tubular epithelial cell death by a mechanism independent of Smad signaling. J Biol Chem. 2003;278(14):12537-12545.

62. Tsutsui H, Nakanishi K, Matsui K, et al. IFN-gamma-inducing factor up-regulates Fas ligand-mediated cytotoxic activity of murine natural killer cell clones. J Immunol. 1996;157(9):3967-3973.

63. Lorz C, Ortiz A, Justo P, et al. Proapoptotic Fas ligand is expressed by normal kidney tubular epithelium and injured glomeruli. J Am Soc Nephrol. 2000;11(7):1266-1277.

64. Ortiz A, Lorz C, Egido J. The Fas ligand/Fas system in renal injury. Nephrol Dial Transplant. 1999;14(8):1831-1834.

65. Lange-Sperandio B, Fulda S, Vandewalle A, Chevalier R. Macrophages induce apoptosis in proximal tubule cells. Pediatr Nephrol. 2003;18(4):335-341.

66. Power R, Doyle B, Higgins D, Brady H, Fitzpatrick J, Watson R. Mechanical deformation induced apoptosis in human proximal renal tubular epithelial cells is caspase dependent. J Urol. 2004;171(1):457-461.

67. Lieberthal W, Menza S, Levine J. Graded ATP depletion can cause necrosis or apoptosis of cultured mouse proximal tubular cells. Am J Physiol. 1998;274(2 Pt 2):F315-F327.

68. Lieberthal W, Levine J. Mechanisms of apoptosis and its potential role in renal tubular epithelial cell injury. Am J Physiol. 1996;271(3 Pt 2): F477-F488.

69. Miyajima A, Chen J, Poppas D, Vaughan EJ, Felsen D. Role of nitric oxide in renal tubular apoptosis of unilateral ureteral obstruction. Kidney Int. 2001;59(4):1290-1303. 
70. Strutz F, Zeisberg M. Renal fibroblasts and myofibroblasts in chronic kidney disease. J Am Soc Nephrol. 2006;17(11):2992-2998.

71. Qi W, Chen X, Poronnik P, Pollock C. The renal cortical fibroblast in renal tubulointerstitial fibrosis. Int J Biochem Cell Biol. 2006;38(1):1-5.

72. Strutz F. How many different roads may a cell walk down in order to become a fibroblast? J Am Soc Nephrol. 2008;19(12):2246-2248.

73. Lin S, Kisseleva T, Brenner D, Duffield J. Pericytes and perivascular fibroblasts are the primary source of collagen-producing cells in obstructive fibrosis of the kidney. Am J Pathol. 2008;173(6):1617-1627.

74. Sakai N, Wada T, Yokoyama H, et al. Secondary lymphoid tissue chemokine (SLC/CCL21)/CCR7 signaling regulates fibrocytes in renal fibrosis. Proc Natl Acad Sci U S A. 2006;103(38):14098-14103.

75. Epstein J, McCarthy G. Progress in HIV and AIDS care. J Can Dent Assoc. 1996;62(11):866-867.

76. Iwano M, Plieth D, Danoff T, Xue C, Okada H, Neilson E. Evidence that fibroblasts derive from epithelium during tissue fibrosis. $J$ Clin Invest. 2002;110(3):341-350.

77. Lee D, Huang E, Ward H. Tight junction biology and kidney dysfunction. Am J Physiol Renal Physiol. 2006;290(1):F20-F34.

78. Lange-Sperandio B, Trautmann A, Eickelberg O, et al. Leukocytes induce epithelial to mesenchymal transition after unilateral ureteral obstruction in neonatal mice. Am J Pathol. 2007;171(3):861-871.

79. Wolf G, Mueller E, Stahl R, Ziyadeh F. Angiotensin II-induced hypertrophy of cultured murine proximal tubular cells is mediated by endogenous transforming growth factor-beta. J Clin Invest. 1993;92(3):1366-1372.

80. Shin G, Kim W, Yim H, Kim M, Kim H. Effects of suppressing intrarenal angiotensinogen on renal transforming growth factor-beta 1 expression in acute ureteral obstruction. Kidney Int. 2005;67(3):897-908.

81. Fern R, Yesko C, Thornhill B, Kim H, Smithies O, Chevalier R. Reduced angiotensinogen expression attenuates renal interstitial fibrosis in obstructive nephropathy in mice. J Clin Invest. 1999;103(1):39-46.

82. Verrecchia F, Chu M, Mauviel A. Identification of novel TGF-beta/ Smad gene targets in dermal fibroblasts using a combined cDNA microarray/promoter transactivation approach. $J$ Biol Chem. 2001;276(20):17058-17062.

83. Kaneto H, Morrissey J, Klahr S. Increased expression of TGF-beta 1 mRNA in the obstructed kidney of rats with unilateral ureteral ligation. Kidney Int. 1993;44(2):313-321.

84. Fukuda K, Yoshitomi K, Yanagida T, Tokumoto M, Hirakata H. Quantification of TGF-beta1 mRNA along rat nephron in obstructive nephropathy. Am J Physiol Renal Physiol. 2001;281(3):F513-F521.

85. Liu Y. Epithelial to mesenchymal transition in renal fibrogenesis: pathologic significance, molecular mechanism, and therapeutic intervention. $J$ Am Soc Nephrol. 2004;15(1):1-12.

86. Fukasawa H, Yamamoto T, Togawa A, et al. Down-regulation of Smad7 expression by ubiquitin-dependent degradation contributes to renal fibrosis in obstructive nephropathy in mice. Proc Natl Acad Sci U S A. 2004;101(23):8687-8692.

87. Taneda S, Hudkins K, Topouzis S, et al. Obstructive uropathy in mice and humans: potential role for PDGF-D in the progression of tubulointerstitial injury. J Am Soc Nephrol. 2003;14(10):2544-2555.

88. Yokoi H, Sugawara A, Mukoyama M, et al. Role of connective tissue growth factor in profibrotic action of transforming growth factor-beta: a potential target for preventing renal fibrosis. Am J Kidney Dis. 2001;38(4 Suppl 1):S134-S138.

89. Mazzieri R, Masiero L, Zanetta L, et al. Control of type IV collagenase activity by components of the urokinase-plasmin system: a regulatory mechanism with cell-bound reactants. EMBOJ. 1997;16(9): 2319-2332.

90. Ishidoya S, Ogata Y, Fukuzaki A, Kaneto H, Takeda A, Orikasa S. Plasminogen activator inhibitor-1 and tissue-type plasminogen activator are up-regulated during unilateral ureteral obstruction in adult rats. $J$ Urol. 2002;167(3):1503-1507.

91. Hruska K, Guo G, Wozniak M, et al. Osteogenic protein-1 prevents renal fibrogenesis associated with ureteral obstruction. Am J Physiol Renal Physiol. 2000;279(1):F130-F143.
92. Zeisberg M, Hanai J, Sugimoto H, et al. BMP-7 counteracts TGFbeta1-induced epithelial-to-mesenchymal transition and reverses chronic renal injury. Nat Med. 2003;9(7):964-968.

93. Itoh S, Thorikay M, Kowanetz M, et al. Elucidation of Smad requirement in transforming growth factor-beta type I receptor-induced responses. J Biol Chem. 2003;278(6):3751-3761.

94. Trachtman H, Futterweit S, Singhal P. Nitric oxide modulates the synthesis of extracellular matrix proteins in cultured rat mesangial cells. Biochem Biophys Res Commun. 1995;207(1):120-125.

95. Shihab F, Yi H, Bennett W, Andoh T. Effect of nitric oxide modulation on TGF-beta1 and matrix proteins in chronic cyclosporine nephrotoxicity. Kidney Int. 2000;58(3):1174-1185.

96. Hochberg D, Johnson C, Chen J, et al. Interstitial fibrosis of unilateral ureteral obstruction is exacerbated in kidneys of mice lacking the gene for inducible nitric oxide synthase. Lab Invest. 2000;80(11):1721-1728.

97. Manucha W, Oliveros L, Carrizo L, Seltzer A, Vallés P. Losartan modulation on NOS isoforms and COX-2 expression in early renal fibrogenesis in unilateral obstruction. Kidney Int. 2004;65(6):2091-2107.

98. Bascands J, Schanstra J. Obstructive nephropathy: insights from genetically engineered animals. Kidney Int. 2005;68(3):925-937.

99. Paul M, Poyan Mehr A, Kreutz R. Physiology of local renin-angiotensin systems. Physiol Rev. 2006;86(3):747-803.

100. Mezzano S, Ruiz-Ortega M, Egido J. Angiotensin II and renal fibrosis. Hypertension. 2001;38(3 Pt 2):635-638.

101. Touyz R, Schiffrin E. Signal transduction mechanisms mediating the physiological and pathophysiological actions of angiotensin II in vascular smooth muscle cells. Pharmacol Rev. 2000;52(4):639-672.

102. Perico N, Benigni A, Remuzzi G. Present and future drug treatments for chronic kidney diseases: evolving targets in renoprotection. Nat Rev Drug Discov. 2008;7(11):936-953.

103. Brenner B, Cooper M, de Zeeuw D, et al. Effects of losartan on renal and cardiovascular outcomes in patients with type 2 diabetes and nephropathy. N Engl J Med. 2001;345(12):861-869.

104. Randomised placebo-controlled trial of effect of ramipril on decline in glomerular filtration rate and risk of terminal renal failure in proteinuric, non-diabetic nephropathy. The GISEN Group (Gruppo Italiano di Studi Epidemiologici in Nefrologia). Lancet. 1997;349(9069):1857-1863.

105. Mathiesen E, Hommel E, Hansen H, Smidt U, Parving H. Randomised controlled trial of long term efficacy of captopril on preservation of kidney function in normotensive patients with insulin dependent diabetes and microalbuminuria. BMJ. 1999;319(7201):24-25.

106. Jafar T, Schmid C, Landa M, et al. Angiotensin-converting enzyme inhibitors and progression of nondiabetic renal disease. A metaanalysis of patient-level data. Ann Intern Med. 2001;135(2):73-87.

107. K/DOQI clinical practice guidelines on hypertension and antihypertensive agents in chronic kidney disease. Am J Kidney Dis. 2004;43 (5 Suppl 1):S1-S290.

108. Strippoli G, Bonifati C, Craig M, Navaneethan S, Craig J. Angiotensin converting enzyme inhibitors and angiotensin II receptor antagonists for preventing the progression of diabetic kidney disease. Cochrane Database Syst Rev. 2006;(4):CD006257.

109. Beharrie A, Franc-Guimond J, Rodriguez M, Au J, Zilleruelo G, Abitbol C. A functional immature model of chronic partial ureteral obstruction. Kidney Int. 2004;65(4):1155-1161.

110. Topcu S, Pedersen M, Nørregaard R, et al. Candesartan prevents longterm impairment of renal function in response to neonatal partial unilateral ureteral obstruction. Am J Physiol Renal Physiol. 2007;292(2): F736-F748.

111. Fujinaka H, Miyazaki Y, Matsusaka T, et al. Salutary role for angiotensin in partial urinary tract obstruction. Kidney Int. 2000;58(5):2018-2027.

112. Chen C, Park M, Forbes M, et al. Angiotensin-converting enzyme inhibition aggravates renal interstitial injury resulting from partial unilateral ureteral obstruction in the neonatal rat. Am J Physiol Renal Physiol. 2007;292(3):F946-F955.

113. Coleman C, Minor J, Burt L, Thornhill B, Forbes M, Chevalier R. Angiotensin AT1-receptor inhibition exacerbates renal injury resulting from partial unilateral ureteral obstruction in the neonatal rat. $A m J$ Physiol Renal Physiol. 2007:293(1):F262-F268. 
114. Zucchetta P, Carasi C, Marzola M, et al. Angiotensin converting enzyme inhibition worsens the excretory phase of diuretic renography for obstructive hydronephrosis. J Urol. 2001;165(6 Pt 2): 2296-2299.

115. Hanssens M, Keirse M, Vankelecom F, Van Assche F. Fetal and neonatal effects of treatment with angiotensin-converting enzyme inhibitors in pregnancy. Obstet Gynecol. 1991;78(1):128-135.

116. Tabacova S, Little R, Tsong Y, Vega A, Kimmel C. Adverse pregnancy outcomes associated with maternal enalapril antihypertensive treatment. Pharmacoepidemiol Drug Saf. 2003;12(8):633-646.

117. Pryde P, Sedman A, Nugent C, Barr MJ. Angiotensin-converting enzyme inhibitor fetopathy. J Am Soc Nephrol. 1993:3(9):1575-1582.

118. Cooper W, Hernandez-Diaz S, Arbogast P, et al. Major congenital malformations after first-trimester exposure to ACE inhibitors. $N E n g l$ J Med. 2006;354(23):2443-2451.

119. Briggs G, Nageotte M. Fatal fetal outcome with the combined use of valsartan and atenolol. Ann Pharmacother. 35(7-8):859-861.

120. Klahr S, Morrissey J. The role of vasoactive compounds, growth factors and cytokines in the progression of renal disease. Kidney Int Suppl. 2000;75:S7-S14.

121. Satoh M, Kashihara N, Yamasaki Y, et al. Renal interstitial fibrosis is reduced in angiotensin II type 1a receptor-deficient mice. J Am Soc Nephrol. 2001;12(2):317-325.

122. Ma J, Nishimura H, Fogo A, Kon V, Inagami T, Ichikawa I. Accelerated fibrosis and collagen deposition develop in the renal interstitium of angiotensin type 2 receptor null mutant mice during ureteral obstruction. Kidney Int. 1998;53(4):937-944.

123. Kaneto H, Morrissey J, McCracken R, Reyes A, Klahr S. Enalapril reduces collagen type IV synthesis and expansion of the interstitium in the obstructed rat kidney. Kidney Int. 1994;45(6):1637-1647.

124. Ferrario C. Angiotensin I, angiotensin II and their biologically active peptides. J Hypertens. 2002;20(5):805-807.

125. Esteban V, Ruperez M, Sánchez-López E, et al. Angiotensin IV activates the nuclear transcription factor-kappaB and related proinflammatory genes in vascular smooth muscle cells. Circ Res. 2005;96(9):965-973.

126. Esteban V, Heringer-Walther S, Sterner-Kock A, et al. Angiotensin(1-7) and the g protein-coupled receptor MAS are key players in renal inflammation. PLoS One. 2009;4(4):e5406.

127. Guo G, Morrissey J, McCracken R, Tolley T, Klahr S. Role of TNFR1 and TNFR2 receptors in tubulointerstitial fibrosis of obstructive nephropathy. Am J Physiol. 1999;277(5 Pt 2):F766-F772.

128. Kent D, Jafar T, Hayward R, et al. Progression risk, urinary protein excretion, and treatment effects of angiotensin-converting enzyme inhibitors in nondiabetic kidney disease. J Am Soc Nephrol. 2007;18(6):1959-1965.

129. Miyajima A, Chen J, Lawrence C, et al. Antibody to transforming growth factor-beta ameliorates tubular apoptosis in unilateral ureteral obstruction. Kidney Int. 2000;58(6):2301-2313.

130. Baricos W, Cortez S, Deboisblanc M, Xin S. Transforming growth factor-beta is a potent inhibitor of extracellular matrix degradation by cultured human mesangial cells. J Am Soc Nephrol. 1999;10(4): 790-795.

131. Waiser J, Dell K, Böhler T, et al. Cyclosporine A up-regulates the expression of TGF-betal and its receptors type I and type II in rat mesangial cells. Nephrol Dial Transplant. 2002;17(9): 1568-1577.

132. Sato M, Muragaki Y, Saika S, Roberts A, Ooshima A. Targeted disruption of TGF-beta1/Smad3 signaling protects against renal tubulointerstitial fibrosis induced by unilateral ureteral obstruction. J Clin Invest. 2003;112(10):1486-1494.

133. Inazaki K, Kanamaru Y, Kojima Y, et al. Smad3 deficiency attenuates renal fibrosis, inflammation, and apoptosis after unilateral ureteral obstruction. Kidney Int. 2004;66(2):597-604.

134. Lan $\mathrm{H}, \mathrm{Mu} \mathrm{W}$, Tomita $\mathrm{N}$, et al. Inhibition of renal fibrosis by gene transfer of inducible Smad7 using ultrasound-microbubble system in rat UUO model. J Am Soc Nephrol. 2003;14(6):1535-1548.
135. Schaefer L, Macakova K, Raslik I, et al. Absence of decorin adversely influences tubulointerstitial fibrosis of the obstructed kidney by enhanced apoptosis and increased inflammatory reaction. Am JPathol. 2002;160(3):1181-1191.

136. Dudas P, Argentieri R, Farrell F. BMP-7 fails to attenuate TGFbeta1-induced epithelial-to-mesenchymal transition in human proximal tubule epithelial cells. Nephrol Dial Transplant. 2009;24(5): 1406-1416.

137. Park S, Choi M, Song I, et al. Erythropoietin decreases renal fibrosis in mice with ureteral obstruction: role of inhibiting TGF-betainduced epithelial-to-mesenchymal transition. J Am Soc Nephrol. 2007;18(5):1497-1507.

138. Vallés P, Pascual L, Manucha W, Carrizo L, Rüttler M. Role of endogenous nitric oxide in unilateral ureteropelvic junction obstruction in children. Kidney Int. 2003;63(3):1104-1115.

139. Morrissey J, Ishidoya S, McCracken R, Klahr S. Nitric oxide generation ameliorates the tubulointerstitial fibrosis of obstructive nephropathy. J Am Soc Nephrol. 1996;7(10):2202-2212.

140. Valles P, Manucha W. H+-ATPase activity on unilateral ureteral obstruction: interaction of endogenous nitric oxide and angiotensin II. Kidney Int. 2000;58(4):1641-1651.

141. Huang A, Palmer L, Hom D, Valderrama E, Trachtman H. The role of nitric oxide in obstructive nephropathy. J Urol. 2000;163(4):1276-1281.

142. Yang J, Shultz R, Mars W, et al. Disruption of tissue-type plasminogen activator gene in mice reduces renal interstitial fibrosis in obstructive nephropathy. J Clin Invest. 2002;110(10):1525-1538.

143. Matsuo S, López-Guisa J, Cai X, et al. Multifunctionality of PAI-1 in fibrogenesis: evidence from obstructive nephropathy in PAI-1-overexpressing mice. Kidney Int. 2005;67(6):2221-2238.

144. Oda T, Jung Y, Kim H, et al. PAI-1 deficiency attenuates the fibrogenic response to ureteral obstruction. Kidney Int. 2001;60(2):587-596.

145. Ingelfinger J. Forestalling fibrosis. $N$ Engl J Med. 2003;349(23): 2265-2266.

146. Fogo A. The potential for regression of renal scarring. Curr Opin Nephrol Hypertens. 2003;12(3):223-225.

147. Miyajima A, Kosaka T, Seta K, Asano T, Umezawa K, Hayakawa M. Novel nuclear factor kappa B activation inhibitor prevents inflammatory injury in unilateral ureteral obstruction. J Urol. 2003;169(4): 1559-1563.

148. Kim K, Lee E, Cha S, et al. Transcriptional regulation of NF-kappaB by ring type decoy oligodeoxynucleotide in an animal model of nephropathy. Exp Mol Pathol. 2009;86(2):114-120.

149. Meldrum K, Metcalfe P, Leslie J, Misseri R, Hile K, Meldrum D. TNF-alpha neutralization decreases nuclear factor-kappaB activation and apoptosis during renal obstruction. J Surg Res. 2006;131(2): 182-188.

150. Rámila D, Ardura J, Esteban V, et al. Parathyroid hormone-related protein promotes inflammation in the kidney with an obstructed ureter. Kidney Int. 2008;73(7):835-847.

151. Klein J, Gonzalez J, Duchene J, et al. Delayed blockade of the kinin $\mathrm{B} 1$ receptor reduces renal inflammation and fibrosis in obstructive nephropathy. FASEB J. 2009;23(1):134-142.

152. Kitagawa K, Wada T, Furuichi K, et al. Blockade of CCR2 ameliorates progressive fibrosis in kidney. Am J Pathol. 2004;165(1):237-246.

153. Tsou C, Peters W, Si Y, et al. Critical roles for CCR2 and MCP-3 in monocyte mobilization from bone marrow and recruitment to inflammatory sites. J Clin Invest. 2007;117(4):902-909.

154. Eis V, Luckow B, Vielhauer V, et al. Chemokine receptor CCR1 but not CCR5 mediates leukocyte recruitment and subsequent renal fibrosis after unilateral ureteral obstruction. J Am Soc Nephrol. 2004;15(2):337-347.

155. Anders H, Vielhauer V, Frink M, et al. A chemokine receptor CCR-1 antagonist reduces renal fibrosis after unilateral ureter ligation. J Clin Invest. 2002;109(2):251-259.

156. Ophascharoensuk V, Giachelli C, Gordon K, et al. Obstructive uropathy in the mouse: role of osteopontin in interstitial fibrosis and apoptosis. Kidney Int. 1999;56(2):571-580. 
157. Inguaggiato $P$, Gonzalez-Michaca L, Croatt A, Haggard J, Alam J, Nath K Cellular overexpression of heme oxygenase-1 up-regulates p21 and confers resistance to apoptosis. Kidney Int. 2001;60(6):2181-2191.

158. Ophascharoensuk V, Fero M, Hughes J, Roberts J, Shankland S. The cyclin-dependent kinase inhibitor p27Kip1 safeguards against inflammatory injury. Nat Med. 1998;4(5):575-580.

159. Chevalier R, Peters C. Congenital urinary tract obstruction: Proceedings of the State-Of-The-Art Strategic Planning Workshop-National Institutes of Health, Bethesda, Maryland, USA, 11-12 2002. Pediatr Nephrol. 2003;18(6):576-606.

160. Huang W, Peters C, Zurakowski D, et al. Renal biopsy in congenital ureteropelvic junction obstruction: evidence for parenchymal maldevelopment. Kidney Int. 2006;69(1):137-143.

161. Chevalier R. Biomarkers of congenital obstructive nephropathy: past, present and future. J Urol. 2004;172(3):852-857.

162. Yang Y, Hou Y, Wang C, Ji S. Renal expression of epidermal growth factor and transforming growth factor-beta1 in children with congenital hydronephrosis. Urology. 2006;67(4):817-821.

163. Yang Y, Zhou X, Gao H, Ji S, Wang C. The expression of epidermal growth factor and transforming growth factor-betal in the stenotic tissue of congenital pelvi-ureteric junction obstruction in children. $J$ Pediatr Surg. 2003;38(11):1656-1660.

164. Palmer L, Maizels M, Kaplan W, Firlit C, Cheng E. Urine levels of transforming growth factor-beta 1 in children with ureteropelvic junction obstruction. Urology. 1997;50(5):769-773.

165. El-Sherbiny M, Mousa O, Shokeir A, Ghoneim M. Role of urinary transforming growth factor-betal concentration in the diagnosis of upper urinary tract obstruction in children. J Urol. 2002; 168(4 Pt 2):1798-1800.

166. Furness Pr, Maizels M, Han S, Cohn R, Cheng E. Elevated bladder urine concentration of transforming growth factor-betal correlates with upper urinary tract obstruction in children. J Urol. 1999; 162(3 Pt 2):1033-1036.

167. Taha M, Shokeir A, Osman H, Abd El-Aziz AA, Farahat S. Pelviureteric junction obstruction in children: the role of urinary transforming growth factor-beta and epidermal growth factor. BJU Int. 2007;99(4):899-903.

168. Haramaki R, Tamaki K, Fujisawa M, Ikedo H, Haramaki N, Okuda S. Steroid therapy and urinary transforming growth factor-beta1 in IgA nephropathy. Am J Kidney Dis. 2001;38(6):1191-1198.

169. De Muro P, Faedda R, Fresu P, et al. Urinary transforming growth factor-beta 1 in various types of nephropathy. Pharmacol Res. 2004;49(3):293-298.

170. Mas V, Maluf D, Archer K, et al. Establishing the molecular pathways involved in chronic allograft nephropathy for testing new noninvasive diagnostic markers. Transplantation. 2007;83(4):448-457.

171. Honkanen E, Teppo A, Törnroth T, Groop P, Grönhagen-Riska C. Urinary transforming growth factor-beta 1 in membranous glomerulonephritis. Nephrol Dial Transplant. 1997;12(12):2562-2568.

172. Knerr I, Nyul Z, Miller J, et al. Increased endothelin-1 and decreased adrenomedullin gene expression in the stenotic tissue of congenital pelvi-ureteric junction obstruction in children. BJU Int. 2001;87(7):667-671.
173. Grandaliano G, Gesualdo L, Bartoli F, et al. MCP-1 and EGF renal expression and urine excretion in human congenital obstructive nephropathy. Kidney Int. 2000;58(1):182-192.

174. Bartoli F, Gesualdo L, Paradies G, et al. Renal expression of monocyte chemotactic protein-1 and epidermal growth factor in children with obstructive hydronephrosis. J Pediatr Surg. 2000;35(4): 569-572.

175. Taha M, Shokeir A, Osman H, Abd el-Aziz AA, Farahat S. Diagnosis of ureteropelvic junction obstruction in children: role of endothelin-1 in voided urine. Urology. 2007;69(3):560-564.

176. Chiou Y, Chiu N, Wang S, Cheng H, Tang M. Factors associated with the outcomes of children with unilateral ureteropelvic junction obstruction. J Urol. 2004;171(1):397-402.

177. Shokeir A, Taha M. Role of urinary tubular enzymes in evaluation of children with ureteropelvic junction narrowing under conservative management. Urology. 2009;73(5):1016-1020.

178. Carr M, Peters C, Retik A, Mandell J. Urinary levels of the renal tubular enzyme N-acetyl-beta-D-glucosaminidase in unilateral obstructive uropathy. J Urol. 1994;151(2):442-445.

179. Taha M, Shokeir A, Osman H, Abd El-Aziz AA, Farahat S. Obstructed versus dilated nonobstructed kidneys in children with congenital ureteropelvic junction narrowing: role of urinary tubular enzymes. J Urol. 2007;178(2):640-646.

180. Shokeir A. Role of urinary biomarkers in the diagnosis of congenital upper urinary tract obstruction. Indian J Urol. 2008;24(3): 313-319.

181. Benito-Martín A, Ucero A, Santamaría B, et al. Transcriptomics illustrate a deadly TRAIL to diabetic nephropathy. Nefrologia. 2009;29(1):13-19.

182. Seseke F, Thelen P, Ringert R. Characterization of an animal model of spontaneous congenital unilateral obstructive uropathy by cDNA microarray analysis. Eur Urol. 2004;45(3):374-381.

183. Higgins D, Lappin D, Kieran N, et al. DNA oligonucleotide microarray technology identifies fisp-12 among other potential fibrogenic genes following murine unilateral ureteral obstruction (UUO): modulation during epithelial-mesenchymal transition. Kidney Int. 2003;64(6):2079-2091.

184. Hauser P, Kainz A, Perco P, et al. Transcriptional response in the unaffected kidney after contralateral hydronephrosis or nephrectomy. Kidney Int. 2005;68(6):2497-2507.

185. Silverstein D, Travis B, Thornhill B, et al. Altered expression of immune modulator and structural genes in neonatal unilateral ureteral obstruction. Kidney Int. 2003;64(1):25-35.

186. Kypreou K, Kavvadas P, Karamessinis P, et al. Altered expression of calreticulin during the development of fibrosis. Proteomics. 2008;8(12):2407-2419.

187. Decramer S, Wittke S, Mischak H, et al. Predicting the clinical outcome of congenital unilateral ureteropelvic junction obstruction in newborn by urinary proteome analysis. Nat Med. 2006;12(4):398-400.

188. Vlahou A, Schanstra J, Frokiaer J, et al. Establishment of a European Network for Urine and Kidney Proteomics. J Proteomics. 2008;71(4):490-492.
Open Access Journal of Urology

\section{Publish your work in this journal}

The Open Access Journal of Urology is an international, peer-reviewed, open access journal publishing original research, reports, editorials, reviews and commentaries on all aspects of adult and pediatric urology in the clinic and laboratory including the following topics: Pathology, pathophysiology of urological disease; Investigation and treatment of

\section{Dovepress}

urological disease; Pharmacology of drugs used for the treatment of urological disease. The manuscript management system is completely online and includes a very quick and fair peer-review system, which is all easy to use. Visit http://www.dovepress.com/testimonials.php to read real quotes from published authors. 